\title{
Atheroma and the inflammasome
}

\author{
H. William Strauss, $M D^{\mathrm{a}}$ \\ ${ }^{a}$ Molecular Imaging and Therapy Service, Department of Radiology, Memorial Sloan Kettering \\ Cancer Center, New York, NY
}

Received Jan 29, 2015; accepted Jan 30, 2015

doi: 10.1007/s12350-015-0086-7

\section{See related article, pp. 1179-1186}

Atherosclerosis is a ubiquitous disorder that begins in childhood. An autopsy study of 2,876 adolescents and young adults (ages 15-34) who died of external causes found fatty streaks in the aorta of $100 \%$ of subjects, and in the right coronary artery in half the subjects. ${ }^{1}$ The number and extent of lesions increased with age. The incidence of fibrous plaque, a marker of a healed lesion in males was $\sim 3 \%$ in subjects $15-19$, increasing to $\sim 20 \%$ in the 30-34-year-old group, suggesting that the lesions evolve over time. Macroscopic calcium in the lesion, however, was rare in these young subjects, $<1 \%$ in subjects ranging from 15 to 29 years of age, increasing slightly to $\sim 1 \%$ in the $30-34$-year-old age group.

The pervasive presence of atheroma suggests that some of these lesions will progress to cause clinical disease. Cerebral transient ischemic attacks and stroke are major clinical manifestations of atherosclerosis in the carotid artery. ${ }^{2}$ An estimated 6.6 million men and women $>20$ years of age in the US have a history of stroke. ${ }^{1}$ Approximately, 795,000 people experience a new or recurrent (ischemic or hemorrhagic) stroke each year. Approximately, 610,000 of these are first events and 185,000 are recurrent stroke events. In 2011, stroke caused 140,000 deaths in the US. The most common therapy for patients with severe carotid stenosis, stroke, or recurrent transient ischemic attacks is carotid endarterectomy.

Approximately, 100,000 endarterectomy procedures were performed in the US in $2010 .^{2}$ Although carotid stenting has gained popularity (accounting for $\sim 13 \%$ of carotid artery revascularization in 2008), a randomized trial of outcomes in 2,502 patients after carotid stenting

Reprint requests: H. William Strauss, MD, Molecular Imaging and Therapy Service, Department of Radiology, Memorial Sloan Kettering Cancer Center, Room S113A, 1275 York Avenue, New York, NY 10065; straussh@mskcc.org

J Nucl Cardiol 2015;22:1187-90.

1071-3581/\$34.00

Copyright (C) 2015 American Society of Nuclear Cardiology. or endarterectomy suggested that in patients over the age of $70^{3}$, there was a lower rate of recurrent stroke in endarterectomy patients.

Characteristics of carotid plaques at risk of causing a clinical event include: ${ }^{4,5}$ Thin fibrous cap $(<65 \mu \mathrm{m})$, large lipid core, evidence of intraplaque hemorrhage, and active plaque inflammation. Additional characteristics of unstable plaque are eccentric distribution of the lesion (due to arterial remodeling) and an irregular surface. ${ }^{4}$ An intact thick fibrous cap (seen on CT, MR or US) has a low risk of rupture, a thin cap is associated with a mild risk of rupture and a fissured fibrous cap is associated with a high risk of rupture (often due to shear stress). ${ }^{6}$ Another common cause of plaque rupture is a sudden increase in plaque volume and pressure due to intraplaque hemorrhage, as is commonly seen in coronary lesions. ${ }^{7,8}$ A large number of macrophages and a necrotic core increase the likelihood of intraplaque hemorrhage due to the release of enzymes within the atheroma (e.g., matrix metalloproteinases ${ }^{9}$ ) that weaken the fragile vasavasorum.

At the time a fatty streak develops, injured endothelium and lipid laden macrophages produce chemoattractant molecules. ${ }^{10}$ The quantity of integrin produced increases as inflammation and lesion size progress. ${ }^{11}$ Progression of inflammation in atheroma causes participation of the immune system, attracting cytolytic T cells into the lesion. ${ }^{12}$ These $\mathrm{T}$ cells promote cytolysis and apoptosis of smooth muscle cells, endothelial cells, and macrophages. Plaque mineralization, once considered a 'tombstone' of atheroma, is now appreciated as a marker with a bimodal distribution. Initial calcium deposition is scattered in necrotic areas and in the cap. This microcalcification (calcium aggregates $<60 \mu \mathrm{m}$ ) occurs in response to proinflammatory stimuli. ${ }^{13}$ This type of calcification, often visible on fluorine$18\left({ }^{18}\right.$ F-fluoride) imaging and high resolution micro CT in laboratory studies, can increase shear stress on the cap, increasing the likelihood of rupture of a thin fibrous cap plaque. ${ }^{14}$ If inflammation abates, vascular smooth muscle cells may undergo osteogenic 
Table 1. A Partial List of Agents Proposed to Image Atheroma

\begin{tabular}{|c|c|}
\hline Agent & Comment \\
\hline Low-density lipoprotein ${ }^{16}$ & $\begin{array}{l}\text { Localizes in the lipid pool in the lesion; demonstrates the } \\
\text { permeability of the lesion }\end{array}$ \\
\hline $\begin{array}{l}\text { Integrins } \alpha_{v} \beta_{3}^{15,20,21} \text { and Vascular Cell } \\
\text { Adhesion Molecule- } 1 \\
(\text { VCAM- } 1)^{22,23}\end{array}$ & $\begin{array}{l}\text { Binds to monocytes and } \mathrm{T} \text { lymphocytes causing cells to stick to } \\
\text { intact endothelium prior to entering the subendothelium }\end{array}$ \\
\hline Chemoattractant signals $(\mathrm{MCP}-1)^{17}$ & $\begin{array}{l}\text { Receptors expressed on mononuclear cells; causes mononuclear } \\
\text { cells to enter the intima }\end{array}$ \\
\hline $\begin{array}{l}\text { Macrophage colony-stimulating } \\
\text { factor }(M-C S F)^{24}\end{array}$ & $\begin{array}{l}\text { Causes macrophages to express scavenger receptors; Required } \\
\text { for macrophages to live [decreased/absent M-CSF causes } \\
\text { macrophages to undergo apoptosis] }\end{array}$ \\
\hline Matrix metalloproteinases 9,25 & $\begin{array}{l}\text { Overproduction or leakage from damaged macrophages causes } \\
\text { degradation of collagen and destabilization of the plaque cap }\end{array}$ \\
\hline $\begin{array}{l}\text { Antibodies recognizing oxidized } \\
\mathrm{LDL}^{26} \text { and peptides recognizing } \\
\text { oxidized } \mathrm{LDL}^{27}\end{array}$ & $\begin{array}{l}\text { Oxidized LDL is toxic to macrophages, and is abundant in necrotic } \\
\text { lesions and contributes to the inflammatory response }\end{array}$ \\
\hline Heat Shock Proteins (HSP) ${ }^{28}$ & $\begin{array}{l}\text { A modified form of apoptosis in late stage atheroma, Pyroptosis, } \\
\text { induced by severe cell stress, associated with caspase- } 1 \\
\text { expression in macrophages, causes release of HSP }-70 \text { by } \\
\text { dendritic cells in atheroma }\end{array}$ \\
\hline Annexin $V^{29}$ & Provides the 'eat-me' signal to phagocytic cells in the lesion \\
\hline${ }^{18} \mathrm{FDG}^{30}$ & Increased metabolic rate of inflammatory cells in the lesion \\
\hline${ }^{18}$ F Fluoride ${ }^{31}$ & Localizes in ruptured and high-risk lesions \\
\hline
\end{tabular}

transdifferentiation, resulting in the formation of homogeneous sheet-like macrocalcification, stabilizing the plaque. $^{13}$ Lesions with macrocalcification are readily visible on clinical CT.

One approach to imaging late stage carotid atheroma is described in this issue of the Journal. Golestani et $\mathrm{al}^{15}$ incubated a novel $\alpha_{v} \beta_{3}$ fluorine-18 labeled RGD peptide with carotid endarterectomy specimens harvested from 16 patients with symptomatic or stenotic (70\%-99\%) atherosclerotic lesions. The $\alpha_{\mathrm{v}} \beta_{3}$ fluorine-18 labeled RGD peptide (RGD-K5) has nanomolar affinity for integrin expressed on inflamed arterial tissue. Carotid endarterectomy specimens from 3 additional patients were incubated with the tracer and a 550-fold excess of unlabeled RGD-K5 as a blocking study to demonstrate the specificity of uptake. Following incubation, the specimens were washed and imaged with microPET. Localization of the peptide in the 16 endarterectomy specimens was heterogeneous, with foci of greater uptake correlating with the endothelial cell marker CD31 and $\alpha_{v} \beta_{3}$ expression on immune histology. Although the investigators were able to show a correlation between histology and tracer localization, the limited number of random comparisons they performed likely underestimated the histologic significance of the imaging results. The blocking studies demonstrated a 6-fold decrease in RGD-k5 uptake, confirming the specificity of the tracer. The heterogeneity of RGD-K5 uptake in the lesions may also reflect the interval between the patient's last clinical event and the time of endarterectomy. Redgrave et al demonstrated a $20 \%$ decrease in carotid lesion inflammation in endarterectomy specimens obtained $\sim 50$ days after a clinical event, and a further $20 \%$ decline by $\sim 100$ days after the clinical event. ${ }^{5}$

In addition to the integrin described by Golestani, other molecular tracers have been described to image atheroma. The lesion is permeable to low-density lipoprotein bound cholesterol, which can be detected with radiolabeled autologous LDL. ${ }^{16}$ As the endothelial permeability is repaired, residual LDL-cholesterol in the subendothelium results in inflammation. The inflammation causes the endothelial cells to produce chemoattractant peptides. ${ }^{17,18}$ The mononuclear cells attracted to the site may effectively 'treat' the lesion by phagocytosis of the residual LDL-cholesterol, often leaving a small fibrous scar. If there is another episode of damage to the intimal cells, the process is repeated. This repetitive process can occur multiple times, frequently without complete resolution, leaving an area of inflammation and necrosis in the vessel wall. Persistent subendothelial inflammation causes vascular remodeling 
and formation of a fibrous cap, separating the flowing blood from the thrombogenic, inflamed subendothelial atheroma. The agents suggested to image atheroma are part of the inflammasome, ${ }^{19}$ a series of markers that are increased in chronic inflammation. At each phase in the evolution of atheroma, one or more molecular markers have been described to image the lesion. Table 1 is a partial list of agents proposed for this purpose.

Identifying patients with atheroma at high risk of a clinical event at a time when organ function is intact, is a high priority for preventive care. In the case of atheroma, an imaging procedure with high sensitivity for lesion detection and high predictive value for a clinical event within 2 years, is required to be clinically useful. The study by Golestani is one more step along the path to develop such a procedure.

\section{References}

1. Strong JP, Malcolm GT, Tracy RE, Newman WP, Hendrick EE, Cornhill JF. Prevalence and extent of atherosclerosis in adolescents and young adults. JAMA. 1999;281:727-35.

2. Mozzaffarian D, Benjamin EJ, Go AS, et al. Heart disease and stroke statistics: 2015 update. Circulation. 2015;131:e29-322.

3. Voeks JH, Howard G, Roubin GS, Malas MB, Cohen DJ, Sternbergh WC 3rd, Aronow HD, Eskandari MK, Sheffet AJ, Lal BK, Meschia JF, Brott TG, CREST Investigators. Age and outcomes after carotid stenting and endarterectomy: the carotid revascularization endarterectomy versus stenting trial. Stroke. 2011;42: 3484-90.

4. Saba L, Anzidei M, Marincola BC, Piga M, Raz E, Bassareo PB, Napoli A, Mannelli L, Catalaono C, Wintermark M. Imaging of the carotid artery vulnerable plaque. Cardiovasc Intervent Radiol. 2014;37:572-85.

5. Redgrave JN, Lovett JK, Gallagher PJ, Rothwell PM. Histological assessment of 526 symptomatic carotid plaques in relation to the nature and timing of ischemic symptoms: the Oxford plaque study. Circulation. 2006;113:2320-8.

6. Virmani R, Finn AV, Kolodgie FD. Carotid plaque stabilization and progression after stroke or TIA. Arterioscler Thromb Vasc Biol. 2009;29:3-6.

7. Kolodgie FD, Gold HK, Burke AP, Fowler DR, Kruth HS, Weber DK, Farb A, Guerrero LJ, Hayase M, Kutys R, Narula J, Finn AV, Virmani R. Intraplaque hemorrhage and progression of coronary atheroma. N Engl J Med. 2003;349:2316-25.

8. Narula J, Strauss HW. Popcorn plaques. Nat Med. 2007;13:532-4.

9. Ohshima S, Petrov A, Fujimoto S, Zhou J, Azure M, Edwards DS, Murohara T, Narula N, Tsimikas S, Narula J. Molecular imaging of matrix metalloproteinase expression in atherosclerotic plaques of mice deficient in apolipoprotein e or low-density-lipoprotein receptor. J Nucl Med. 2009;50:612-7.

10. Sullivan GW, Sarembock IJ, Linden J. The role of inflammation in vascular diseases. J Leukoc Biol. 2000;67:591-602.

11. Schoen FJ. Blood vessels. In: Kumar V, Abbas AK, Fausto N, editors. Pathologic basis of disease (Chap 11). 7th ed. Philadelphia, PA: Elsevier Saunders; 2005. p. 511-54.

12. Libby P. The vascular biology of atherosclerosis. In: Zipes DP, Libby P, Bobow RO, Braunwald E, editors. Braunwald's heart disease. 7th ed. Philadelphia, PA: Elsevier Saunders; 2005. p. $921-37$.
13. Pugliese G, Iacobini C, Fantauzzi CB, Menini S. The dark and bright side of atherosclerotic calcification. Arteriosclerosis. 2015;282:220-30.

14. Maldonado N, Kelly-Arnold A, Vengrenyuk Y, Laudier D, Fallon JT, Virmani R, Cardoso L, Weinbaum S. A mechanistic analysis of the role of microcalcifications in atherosclerotic plaque stability: potential implications for plaque rupture. Am J Physiol Heart Circ Physiol. 2012;303:619-28.

15. Golestani R, Mirfeizi L, Zeebregts CJ, Westra J, de Haas HJ, Glaudemans AWJM, Koole M, Luurtsema G, Tio RA, Dierckx RAJO, Boersma HH, Elsinga PH, Riemer HJA, Slart RHJA. Feasibility of $\left[{ }^{18} \mathrm{~F}\right]-\mathrm{RGD}$ for ex vivo imaging of atherosclerosis in detection of $\alpha_{\mathrm{v}} \beta_{3}$ integrin expression. J Nucl Cardiol 2015

16. Lees RS, Lees AM, Strauss HW. External imaging of human atherosclerosis. J Nucl Med. 1983;24(2):154-6.

17. Ohtsuki K, Hayase M, Akashi K, Kopiwoda S, Strauss HW. Detection of monocyte chemoattractant protein-1 receptor expression in experimental atherosclerotic lesions: an autoradiographic study. Circulation. 2001;104:203-8

18. Hartung D, Petrov A, Haider N, Fujimoto S, Blankenberg F, Fujimoto A, Virmani R, Kolodgie FD, Strauss HW, Narula J. Radiolabeled monocyte chemotactic protein 1 for the detection of inflammation in experimental atherosclerosis. J Nucl Med. 2007;48:1816-21.

19. Robbins GR, Wen H, Ting JP. Inflammasomes and metabolic disorders: old genes in modern diseases. Mol Cell. 2014;54: 297-308.

20. Laitinen I, Saraste A, Weidl E, Poethko T, Weber AW, Nekolla SG, Leppänen P, Ylä-Herttuala S, Hölzlwimmer G, Walch A, Esposito I, Wester HJ, Knuuti J, Schwaiger M. Evaluation of $\alpha_{\mathrm{v}} \beta_{3}$ integrin-targeted positron emission tomography tracer ${ }^{18} \mathrm{~F}$-galactoRGD for imaging of vascular inflammation in atherosclerotic mice. Circ Cardiovasc Imaging. 2009;2(4):331-8.

21. Saraste A, Laitinen I, Weidl E, Wildgruber M, Weber AW, Nekolla SG, Hölzlwimmer G, Esposito I, Walch A, Leppänen P, Lisinen I, Luppa PB, Ylä-Herttuala S, Wester HJ, Knuuti J, Schwaiger M. Diet intervention reduces uptake of $\alpha_{\mathrm{v}} \beta_{3}$ integrintargeted PET tracer ${ }^{18} \mathrm{~F}$-galacto-RGD in mouse atherosclerotic plaques. J Nucl Cardiol. 2012;19:775-84.

22. Broisat A, Riou LM, Ardisson V, Boturyn D, Dumy P, Fagret D, Ghezzi C. Molecular imaging of vascular cell adhesion molecule-1 expression in experimental atherosclerotic plaques with radiolabelled B2702-p. Eur J Nucl Med Mol Imaging. 2007;34:830-40.

23. Nahrendorf M, Keliher E, Panizzi P, Zhang H, Hembrador S, Figueiredo JL, Aikawa E, Kelly K, Libby P, Weissleder R. 18F-4V for PET-CT imaging of VCAM-1 expression in atherosclerosis. JACC Cardiovasc Imaging. 2009;2:1213-22.

24. Zhang H. 64Cu-DTPA-CLIO-VT680. Mol Imag and Contrast Agent Database (MICAD)

25. Razavian M, Tavakoli S, Zhang J, Nie L, Dobrucki LW, Sinusas AJ, Azure M, Robinson S, Sadeghi MM. Atherosclerosis plaque heterogeneity and response to therapy detected by in vivo molecular imaging of matrix metalloproteinase activation. J Nucl Med. 2011;52:1795-802.

26. Tsimikas S, Palinski W, Halpern SE, Yeung DW, Curtiss LK, Witztum JL. Radiolabeled MDA2, an oxidation-specific, monoclonal antibody, identifies native atherosclerotic lesions in vivo. J Nucl Cardiol. 1999;6(1 Pt 1):41-53.

27. Nishigori K, Temma T, Yoda K, Onoe S, Kondo N, Shiomi M, Ono M, Saji H. Radioiodinated peptide probe for selective detection of oxidized low density lipoprotein in atherosclerotic plaques. Nucl Med Biol. 2013;40:97-103.

28. Bobryshev YV, Lord RS. Expression of heat shock protein-70 by dendritic cells in the arterial intima and its potential significance in atherogenesis. J Vasc Surg. 2002;35:368-75. 
29. Kolodgie FD, Petrov A, Virmani R, Narula N, Verjans JW, Weber DK, Hartung D, Steinmetz N, Vanderheyden JL, Vannan MA, Gold HK, Reutelingsperger CP, Hofstra L, Narula J. Targeting of apoptotic macrophages and experimental atheroma with radiolabeled annexin V: a technique with potential for noninvasive imaging of vulnerable plaque. Circulation. 2003;108:3134-9.

30. Taqueti VR, Di Carli MF, Jerosch-Herold M, Sukhova GK, Murthy VL, Folco EJ, Kwong RY, Ozaki CK, Belkin M, Nahrendorf M, Weissleder R, Libby P. Increased microvascularization and vessel permeability associate with active inflammation in human atheromata. Circ Cardiovasc Imaging. 2014;7(6):920-9.
31. Joshi NV, Vesey AT, Williams MC, Shah AS, Calvert PA, Craighead FH, Yeoh SE, Wallace W, Salter D, Fletcher AM, van Beek EJ, Flapan AD, Uren NG, Behan MW, Cruden NL, Mills NL, Fox KA, Rudd JH, Dweck MR, Newby DE. 18F-fluoride positron emission tomography for identification of ruptured and high-risk coronary atherosclerotic plaques: a prospective clinical trial. Lancet. 2014;383:705-13. 